\title{
Occupational Safety Practice of Hazardous Health-care Waste Management in Bengkulu City
}

\author{
Jipri Suyanto ${ }^{1}$, Wulan Rahmadhani ${ }^{{ }^{2}}$, Yatri Hilinti ${ }^{3}$, Nipaporn Nobnorb ${ }^{4}$, Phan Trieu \\ Phu MD ${ }^{5}$ \\ ${ }^{1}$ Department of Public Heath, Faculty of Health Science, Dehasen University, Indonesia \\ ${ }^{2}$ Department of Midwifery, Sekolah Tinggi Ilmu Kesehatan Muhammadiyah Gombong, \\ Indonesia \\ ${ }^{3}$ Department of Midwifery, Faculty of Health Science, Dehasen University, Indonesia \\ ${ }^{4}$ Public Health Program, Faculty of Science and Technology, Suratthani Rajabhat \\ University, Thailand \\ ${ }^{5} \mathrm{MPH}$ student at Division of Epidemiology and Public Health, Nottingham University, UK \\ *corresponding author, e-mail: wulan@stikesmuhgombong.ac.id
}

Received: 03/02/2021; published: 30/03/2021

\begin{abstract}
Background: Facing many patients while the workers were limited prompted health workers to make a quick decision regarding health-care waste. High workload pressured health workers and put them at risk of getting diseases than others, especially diseases from medical waste that they took care. Besides, as health workers, they should be clean from bacteria or viruses that can transmit diseases to their patients. This research aimed to investigate the factors associated with occupational safety practice of hazardous health-care waste management in Bengkulu City. Method: This cross-sectional study used a stratified random sampling technique to select 230 respondents who work as health workers to respond to a questionnaire interview. The data were analyzed using multivariate logistic regression to find the association between the outcomes and the independent variables. Results: The prevalence of poor occupational safety practice of hazardous health-carewaste management was $35.21 \%(95 \% \mathrm{Cl}=29.27$ 41.66). The factors significantly associated with occupational safety practice of hazardous health-care waste management were; gender ( $p$-value $<0.001$ ), department/unit ( $p$-value < 0.001 ), knowledge ( $p$-value $<0.001$ ), and spirituality ( $p$-value $<0.001$ ). Conclusion: gGnder, department/unit, knowledge, and spirituality were associated with occupational safety practice of hazardous health-carewaste management in Bengkulu City.
\end{abstract}

Keywords: spirituality; knowledge; occupational safety practice; hazardous health-carewaste management.

Copyright $\odot 2013$ Universitas Ahmad Dahlan. All rights reserved.

\section{Introduction}

Hazardous health-care waste is waste from medical services that can be infectious and toxic. WHO global assessment reported that high-income countries have the highest percentage of health-care waste or up to $0.5 \mathrm{~kg}$ per patient every day. Health-care waste made up $58 \%$ of the total waste in the world. Health workers were the easiest group to get infected by diseases from hazardous health-care waste than other workers or $30 \%$ more at risk [1]. Indonesia's statistic board reported that hazardous health-care waste has been increasing in volume, especially Bengkulu [2]. Meanwhile, the ratio of patients and health workers was unbalanced. The number of patients were too many to handle. Thus, the limited-time and energy of health workers was the main problem. It prompted them to take simpler action that were efficient and effective in treating and caring for the patient. Although, they could keep their energy, sometimes they had to deal with a surge of patients. Hence, they forgot to use I protective equipment when they made physical contact with hazardous 
waste. This condition made them more fragile and at high risk of being infected with disease. If health workers get infected with disease from hazardous waste, they can spread it to their patients, spurringd another problem in health care. Not all hospitals in low- and middle-income countries have adequate waste area, especially private hospitals. This problem poses a risk to health workers and makes them more vulnerable to get infected with diseases from hazardous medical waste.

\section{Method}

The research was conducted by following a cross-sectional design. Samples were determined using a stratified random sample. The probability proportional to size was used to calculate the number of married young women in nine hospitals in Bengkulu City. This research involved 230 health workers as the participants who were surveyed using questionnaire. The research result was occupational safety practice of hazardous healthcare waste management. The research result was divided into three groups, namely good, moderate and poor practice. The mean variables of research were knowledge, attitude and spirituality. Using Likert scale, these variables were further divided into three groups, namely good, moderate and poor. This research recruited 230 people as the respondents. The inclusion criteria for respondents were health worker (nurse, public health, doctor, etc.) with more than one year working experience and willing to be respondent. The exclusion criteria was free from complicated disease. The analyses were divided into three-step as a univariate model to show the percentage of every variable, logistic regression and multiple logistic regression to investigate the factors that had a relationship with occupational safety practice of hazardous health-care waste management. All analyses were carried out using Stata version 13.0.

\section{Results and Discussion}

\subsection{Result}

The results obtained indicate that of 124 respondents, most of the respondents were aged between 25 and 30 years (41.67\%). More than half of the total respondents $(60 \%)$ were women. The majority of respondents were muslim $(50 \%)$ and a lot of respondents came from other ethnics (37.83\%). In terms of educational stage, a moderate percentage of respondents had magister degree (38.26\%). Then, almost half of the respondents had the length of employment $\geq 10$ years $(49.13 \%)$. A great percentage of respondents have never had a training of hazardous waste management $(91.30 \%)$ and medical/surgical department made up $20 \%$ of total respondents. Almost half of the respondents had poor knowledge $(44.35 \%)$, others had moderate attitude $(37.83 \%)$ and good spirituality $(82.61 \%)$ got the highest percentage. The result showed that almost half of them had poor occupational safety practices of hazardous waste management. It means that the prevalence of poor occupational safety practice of hazardous waste management was still high. More details can be seen in Table 1.

Table 1. Demographic Characteristics of Respondents

\begin{tabular}{lcc}
\hline Characteristic & $\mathbf{n}$ & $\%$ \\
\hline Age (years) & & \\
$\quad<25$ & 53 & 25.98 \\
$25-30$ & 85 & 41.67 \\
$\geq 31$ & 66 & 32.35 \\
Gender & 92 & \\
$\quad$ Men & 138 & 40 \\
Women & & 60 \\
Religion & 115 & \\
$\quad$ Muslim & 41 & 50 \\
Catholic & 55 & 17.83 \\
Protestant & 11 & 23.91 \\
$\quad$ Buddhist & 8 & 4.78 \\
$\quad$ Hindu & & 3.48 \\
Ethnics & 44 & \\
$\quad$ Rejang ethnic & & \\
\hline
\end{tabular}




\begin{tabular}{|c|c|c|}
\hline Characteristic & $\mathbf{n}$ & $\%$ \\
\hline Basemah ethnic & 20 & 8.70 \\
\hline Lembak ethnic & 18 & 7.83 \\
\hline Muomuko ethnic & 17 & 7.39 \\
\hline Pekal ethnic & 12 & 5.22 \\
\hline Serawai ethnic & 13 & 5.65 \\
\hline Kaur ethnic & 7 & 3.04 \\
\hline Enggano ethnic & 12 & 5.22 \\
\hline Other ethnics & 87 & 37.83 \\
\hline \multicolumn{3}{|l|}{ Education } \\
\hline Diploma & 8 & 3.48 \\
\hline Bachelor & 134 & 58.26 \\
\hline Magister & 88 & 38.26 \\
\hline \multicolumn{3}{|c|}{ Length of employment (years) } \\
\hline$<10$ years & 117 & 50.87 \\
\hline$\geq 10$ years & 113 & 49.13 \\
\hline \multicolumn{3}{|c|}{ Training of hazardous waste management } \\
\hline Ever & 20 & 8.70 \\
\hline Never & 210 & 91.30 \\
\hline \multicolumn{3}{|l|}{ Department/unit } \\
\hline Others & 53 & 23.04 \\
\hline Pediatric & 56 & 24.35 \\
\hline ICU & 38 & 16.52 \\
\hline Emergency & 34 & 14.78 \\
\hline OR & 3 & 1.30 \\
\hline Medical/surgical & 46 & 20 \\
\hline \multicolumn{3}{|l|}{ Knowledge } \\
\hline Good & 71 & 30.87 \\
\hline Moderate & 57 & 24.78 \\
\hline Poor & 102 & 44.35 \\
\hline \multicolumn{3}{|l|}{ Attitude } \\
\hline Good & 75 & 32.61 \\
\hline Moderate & 87 & 37.83 \\
\hline Poor & 68 & 29.57 \\
\hline \multicolumn{3}{|l|}{ Spirituality } \\
\hline Good & 190 & 82.61 \\
\hline Moderate & 25 & 10.87 \\
\hline Poor & 15 & 6.52 \\
\hline \multicolumn{3}{|l|}{ Safety Care Practice } \\
\hline Good & 109 & 47.39 \\
\hline Moderate & 40 & 17.39 \\
\hline Poor & 81 & 35.21 \\
\hline
\end{tabular}

Variables with the highest association with occupational safety practice of hazardous waste management were moderate-poor of spirituality (Crude PR $=8.47$; Adj. PR $=17.05$; $95 \% \mathrm{Cl}=3.91-74.46 ; \mathrm{p}<0.001)$ followed by emergency department/unit (Crude $\mathrm{PR}=$ 8.32; Adj. $\mathrm{PR}=16.29 ; 95 \% \mathrm{Cl}=3.02-87.84 ; \mathrm{p}<0.001$ ), and poor knowledge (Crude $\mathrm{PR}=$ 5.99; Adj. $\mathrm{PR}=12.11 ; 95 \% \mathrm{Cl}=3.81-38.44 ; \mathrm{p}<0.001)$. More details can be seen in Table 2. 
Table 2. Multivariate Analysis Results

\begin{tabular}{lcccccc}
\hline \multicolumn{1}{c}{ Variabel } & $\mathbf{n}$ & $\%$ & $\begin{array}{c}\text { Crude } \\
\text { PR }\end{array}$ & $\begin{array}{c}\text { Adjusted } \\
\text { PR }\end{array}$ & 95\% Cl & p-value \\
& & & & & & $<0.001$ \\
\hline $\begin{array}{l}\text { Gender } \\
\quad \text { Men }\end{array}$ & 58 & 63.04 & 1 & 1 & & \\
$\quad$ Women & 23 & 16.67 & 0.17 & 0.11 & $0.04-0.31$ & $<0.001$ \\
$\begin{array}{l}\text { Department/unit } \\
\text { Others }\end{array}$ & 4 & 7.55 & 1 & 1 & & \\
$\quad$ Pediatric & 16 & 28.57 & 8.76 & 20.6 & $4.26-99.63$ & \\
$\quad$ ICU & 31 & 81.58 & 76.67 & 717.62 & $77.73-6625.31$ & \\
$\quad$ Emergency & 11 & 32.35 & 8.32 & 16.29 & $3.02-87.84$ & \\
$\quad$ OR-Medical / surgical & 19 & 38.78 & 8.76 & 30.23 & $6.04-151.22$ & \\
Knowledge & & & & & & $<0.001$ \\
$\quad$ Good & 8 & 11.27 & 1 & 1 & & \\
$\quad$ Moderate & 22 & 38.60 & 65.15 & 78.98 & $17.75-351.54$ & \\
$\quad$ Poor & 51 & 50 & 5.99 & 12.11 & $3.81-38.44$ & \\
Spirituality & 61 & 32.11 & 1 & 1 & & $<0.001$ \\
$\quad$ Good & 20 & 50 & 8.47 & 17.05 & $3.91-74.46$ & \\
$\quad$ Moderate - Poor & & & & & & \\
\hline
\end{tabular}

\subsection{Discussion}

Previous studies have stated that the main cause of anemia in Indonesia is a lack of knowledge about anemia which results in a high rate of anemia. Therefore, it is necessary to carry out educational activities regarding anemia, the dangers of anemia and prevention so that the prevalence of anemia among adolescent girls can be suppressed [10]. One of the causes of the high prevalence rate of anemia is the unhealthy diet of adolescents. Lack of knowledge about anemia causes unhealthy adolescent eating patterns, resulting in bad attitudes and behavior in term of health [11].

This study aimed to find the factors associated with occupational safety practice of hazardous health-care waste management in Bengkulu City, Indonesia. The findings revealed that moderate-poor spirituality was the highest variable in correlation with occupational safety practice of hazardous waste management, followed by emergency department/unit, and poor knowledge.

Estimation of hazardous health-care waste in Indonesia rose to 296, 86 ton per day with $30 \%$ risk of health workers getting infected. Hazardous health-care waste has increased by $50 \%$ lately [2]. It means that the opportunity or the risk prevalence to get infected among health workers is increasing.

A good practice is the key that can influence patient's perceptions on management service quality [3]. Patients do not trust hospital with a bad reputation I of occupational safety practice because it risks their health [4]. Moreover, it is possible for them to be infected with other diseases [5]. Nurses' adherence to occupational safety practices of hazardous waste management is the key to keep the health of health workers and patient's beliefs [6]. Besides, working overtime was not good and increase the risk to get infected for health workers whose job is dealing with hazardous health-care waste [7].

Gender could be the predictor of immune system. In general, women are more fragile than men. A previous study reported that women living near waste area of hospital were more at risk from birth defects [8]. Another research also found that gender was associated with HCW segregation practice with AOR: 1.70 [9].

Each department of hospital had different function and duty. However, it does not mean that some departments are not related to the risk of disease from hazardous health-care waste. Previous research found that housekeeping department was more at risk to be infected with disease from health-care waste [10]. Knowledge is crucial in proper waste management, particularly the knowledge to protect one's self from hazardous health-care waste. Previous study found that health workers who had poor knowledge was more at risk to experience the harmful effects from inadequate healthcare waste management [11]. 
Nurses' spirituality is the belief related to their emotion and their job to provide a service to the patient. Previous research found that belief was associated with medical waste disposal practice [12]. Compared to previous studies in Indonesia, this research used interview to gather the data. The quantitative method can be considered conservative. Although the study related to occupational safety practice of hazardous waste management is still lacking, several studies have investigated the association betweenmoderate-poor spirituality, emergency department/unit, poor knowledge, and occupational safety practice of hazardous health-care waste management [13-15].

This research was conducted in the form of a survey at all hospitals in Bengkulu City with health workers as the respondents. Examining all 10 regencies in Bengkulu City is beyond the scope of this study. Therefore, this research does not represent all hospitals in Bengkulu Province.

\section{Conclusion}

Gender, department/unit, knowledge, and spirituality were associated with occupational safety practice of hazardous health-care waste management in Bengkulu City. The hospital should provide training to the nurse to treat the hazardous waste appropriately. It can help the hospital build nurses' awarness of the hazardous waste effects, especially their health and patient health.

\section{References}

1. WHO. Health-care waste. 2018. https://www.who.int/news-room/fact-sheets/detail/healthcare-waste

2. Central Bureau of Statistics. Indonesian Environmental Statistics 2019. Badan Pusat Statistik. 2019. 1-224.

3. Lim, J. H., Ahn, J. W., \& Son, Y. J. Association between Hospital Nurses' Perception of Patient Safety Management and Standard Precaution Adherence: A Cross-Sectional Study. International Journal of Environmental Research and Public Health. 2019;16(23):1-12.

4. Rezeki, S. Kesehatan dan Keselamatan Kerja. Pusdik SDM Kesehatan. Jakarta. 2016.

5. Alja'afreh, M. A., Mosleh, S. M., \& Habashneh, S. S. Nurses' Perception and Attitudes Towards Oral Care Practices for Mechanically Ventilated Patients. Saudi Medical Journal. 2018;39(4):379-385.

6. Vaismoradi, M., Tella, S., Logan, P. A., Khakurel, J., \& Vizcaya-Moreno, F. Nurses' Adherence to Patient Safety Principles: A Systematic Review. International Journal of Environmental Research and Public Health. 2020;17(6):1-15.

7. Ndejjo, R., Musinguzi, G., Yu, X., Buregyeya, E., Musoke, D., Wang, J. S., Halage, A. A., Whalen, C., Bazeyo, W., Williams, P., \& Ssempebwa, J. Occupational Health Hazards Among Healthcare Workers in Kampala, Uganda. Journal of Environmental and Public Health. 2015.

8. Kihal-Talantikite, W., Zmirou-Navier, D., Padilla, C., \& Deguen, S. Systematic Literature Review of Reproductive Outcome Associated with Residential Proximity to Polluted Sites. International Journal of Health Geographics. 2017;16(20):1-39.

9. Sahiledengle, B. Self-Reported Healthcare Waste Segregation Practice and Its Correlate Among Healthcare Workers in Hospitals of Southeast Ethiopia. BMC Health Services Research. 2019;19(1):1-11.

10. Karki, S., Niraula, S. R., \& Karki, S. Perceived Risk and Associated Factors of Healthcare Waste in Selected Hospitals of Kathmandu, Nepal. PLoS ONE. 2020;15(7):1-10.

11. Wafula, S. T., Musiime, J., \& Oporia, F. Health Care Waste Management Among Health Workers and Associated Factors in Primary Health Care Facilities in Kampala City, Uganda: A Cross-sectional Study. BMC Public Health. 2019;19(1):1-10.

12. Udofia, E. A., Gulis, G., \& Fobil, J. Solid Medical Waste: A Cross Sectional Study of Household Disposal Practices and Reported Harm in Southern Ghana. BMC Public Health. 2017;17(1):1-12.

13. Rimantho, D. Identifikasi Risiko Kesehatan dan Keselamatan Kerja pada Pekerja Pengumpulan Sampah Manual di Jakarta Selatan. Jurnal Optimasi Sistem Industri. 2015;14(1):1-15. 
Disease Prevention and Public Health Journal

ISSN: 2720-9997

14. Rimantho, D. Identifikasi Risiko Kesehatan dan Keselamatan Kerja pada Pekerja Pengumpul Sampah Manual di Jakarta Selatan. Jurnal Optimasi Sistem Industri. 2016;14(1):1-15.

15. Sari, P. F. O. Faktor-Faktor yang Berhubungan dengan Praktik Pengelolaan Limbah Medis Padat Puskesmas Cawas I Kabupaten Klaten. Jurnal Kesehatan Masyarakat. 2018;6(4):505-514. 